\title{
PENGARUH TEKNOLOGI INFORMASI, KOMPETENSI, DAN KOMPENSASI TERHADAP KINERJA PENGELOLAAN KEUANGAN PADA BADAN PENGELOLAAN KEUANGAN DAN ASSET DAERAH (BPKAD) KOTA BAUBAU
}

\author{
Fariz Mustaqim \\ Program Studi Akuntansi, Fakultas Ekonomi \\ Universitas Muhammadiyah Buton, Baubau, Indonesia \\ Email: farizmustaqim5@gmail.com
}

\begin{abstract}
ABSTRAK
Penelitian ini bertujuan untuk menguji dan menganalisis signifikansi pengaruh teknologi informasi terhadap kinerja pengelolaan keuangan, Untuk menguji dan menganalisis signifikansi pengaruh kompetensi terhadap kinerja pengelolaan keuangan, Untuk menguji dan menganalisis signifikansi pengaruh kompensasi terhadap kinerja pengelolaan keuangan, Untuk menguji dan menganalisis variabel yang lebih dominan berpengaruh terlhadap kinerja keuangan. Jenis penelitian ini adalah penelitian kuantitatif. Objek Penelitian ini adalah Badan Pengelolaan Keuangan dan Asset Daerah (BPKAD) di Kota Baubau. Teknik pengambilan sampel menggunakan teknik sensus yaitu seluruh pegawai Badan Pengelolaan Keuangan dan Asset Daerah Kota Baubau. Metode pengumpulan data dilakukan dengan kuesioner dan diolah dengan menggunakan aplikasi statistik SPSS. Hasil penelitian menunjukkan bahwa teknologi informasi berpengaruh positif dan signifikan terhadap kinerja pengelolaan keuangan; kompetensi berpengaruh positif dan signifikan terhadap kinerja pengelolaan keuangan; kompensasi berpengaruh positif dan signifikan terhadap kinerja pengelolaan keuangan; teknologi informasi merupakan variabel yang lebih dominan berpengaruh terhadap kinerja pengelolaan keuangan.
\end{abstract}

Kata Kunci : Teknologi Informasi, Kompetensi, Kompensasi, dan Kinerja Pengelolaan Keuangan

\section{ABSTRACT}

This research aims to examine and analyze the significant effect of information technology, competency, compensation, on the performance of financial management as well as to analyze variables more dominant influence on the performance of financial management. It is a quantitative research. The object of the study at Badan Pengelolaan Keuangan dan Asset Daerah (BPKAD) in Baubau city. The sampling technique used census techniques which concern all civil servants of the Agency. Data collection method is done by questionnaires and analyzed using SPSS. The results showed that information technology, competence, and compensation have influence significantly and 
positively to the performance of financial management on the Board and also information technology is variable more dominant influence to the financial management performance.

Keywords : Information Technology, Competence, Compensation, and Performance Financial Management

\section{PENDAhuluan}

Perkembangan teknologi diiringi dengan perkembangan sistem informasi yang berbasis teknologi yang meliputi perkembangan infrastruktur teknologi informasi. Perkembangan sistem informasi tersebut perlu didukung banyak faktor yang diharapkan dapat memberikan kesuksesan dari sistem informasi itu sendiri yang tercermin melalui kepuasan pemakai sistem informasi. Proses berkembangnya teknologi informasi tidak hanya mempengaruhi dunia bisnis, tetapi juga mempengaruhi bidang-bidang lain seperti kesehatan, pendidikan, pemerintahan, dan lain-lain [1].

Investasi di bidang teknologi informasi dalam suatu organisasi sebagian besar bertujuan untuk dapat memberikan kontribusi yang positif terhadap kinerja. Investasi dibidang teknologi informasi memberikan kontribusi terhadap kinerja dan produktivitas suatu organisasi [2].

Indonesia memasuki dimensi baru dalam matriks kehidupan masyarakat dengan diberlakukannya kebijakan otonomi daerah. Sejalan dengan menguatnya tuntutan ekonomi, tumbuhlah pemikiran tentang desentralisasi. Untuk mengakomodasi hal itu terbitlah Undang-Undang Nomor 32 Tahun 2004 tentang Pemerintah Daerah yang merupakan penyempurnaan dari Undang-Undang Nomor 22 Tahun 1999. Penerapan otonomi daerah seutuhnya membawa konsekuensi logis berupa penyelenggaraan pemerintah dan pembangunan berdasarkan manajemen keuangan yang sehat. Sesuai ketentuan peraturan perundangan yang telah ditetapkan, pemerintah daerah berkewajiban untuk membuat laporan pertanggungjawaban keuangan yang terdiri atas laporan perhitungan anggaran, neraca, laporan arus kas dan nota perhitungan anggaran. Pemberian otonomi yang luas dan desentralisasi, membuka jalan bagi pemerintah untuk melakukan pengelolaan keuangan daerah yang berorientasi pada kepentingan publik. Pasal 4 Peraturan Pemerintah Nomor 105 Tahun 2000 tentang Pengelolaan dan Pertanggungjawaban Keuangan Daerah menegaskan bahwa pengelolaan keuangan daerah harus dilakukan secara tertib, taat pada peraturan perundang-undangan yang berlaku, 
efisien, efektif, transparan dan bertanggung jawab dengan memperhatikan asas keadilan dan kepatuhan [3].

Kemampuan daerah dalam mengelola keuangan dituangkan dalam APBD yang langsung maupun tidak langsung mencerminkan kemampuan pemerintah daerah dalam membiayai pelaksanaan tugas-tugas pemerintahan, pembangunan dan pelayanan sosial masyarakat. Evaluasi terhadap pengelolaan keuangan daerah dan pembiayaan keuangan daerah akan sangat menentukan kedudukan suatu pemerintah daerah dalam rangka melaksanakan otonomi daerah [4].

Pemerintah daerah merupakan salah satu organisasi sektor publik yang mengelola anggaran pemerintah dengan berbagai kebijakan dan program dengan harapan menghasilkan manfaat yang sebesar-besarnya bagi masyarakat di daerahnya. Sebagai instansi dan organisasi sektor publik yang menggunakan dana dari masyarakat melalui pajak, pemerintah daerah bertanggung jawab memenuhi akuntabilitas dan harapan masyarakat. Dalam rangka mewujudkan pelayanan yang maksimal, organisasi dan instansi dalam sektor publik harus memiliki tata kelola yang baik (good governance), sehingga dalam kinerjanya dapat menghasilkan manfaat bagi masyarakat dan anggotanya. Selain itu, untuk mewujudkan kinerja yang baik maka pemerintah daerah harus dapat mengambil keputusan yang tepat yang akan direalisasikan dalam bentuk program kerja dengan tujuan mensejahterakaan masyarakat [5].

Kompetensi merupakan kombinasi antara ilmu pengetahuan dan kemampuan seseorang dalam mengerjakan sesuatu atau memecahkan masalah. Kompetensi pemakai dalam mengoperasikan sistem dapat dilihat dari seberapa besar pengetahuan dan kemampuan yang dimiliki pemakai untuk mengidentifikasi, mengolah, mengakses dan menginterpretasikan data dalam bentuk informasi akuntansi yang berkualitas. Seiring dengan perkembangan teknologi, maka tingkat kompetensi pemakai dalam pengoperasian sistem juga harus terus meningkat. Untuk meningkatkan kompetensi pemakai dapat dilakukan dengan berbagai cara antara lain melalui pendidikan khusus, pengalaman dan pelatihan dibidang sistem informasi dan teknologi komputer [5].

Dalam rangka meningkatkan kinerja pengelolaan keuangan daerah, maka banyak faktor yang perlu dipertimbangkan, diantaranya adalah kompetensi dan kompensasi. Kompetensi merupakan pengetahuan, keterampilan dan kemampuan yang dikuasai oleh seseorang yang telah menjadi bagian dari dirinya, sehingga ia dapat melakukan perilakuperilaku kognitif, afektif dan psikomotorik dengan sebaik-baiknya [6]. Kompetensi dapat 
memperdalam dan memperluas kemampuan kerja. Semakin seseorang melakukan pekerjaan yang sama, maka semakin terampil dan semakin cepat pula dia menyelesaikan pekerjaan tersebut [7].

Selain kompetensi, kompensasi juga merupakan salah satu faktor yang menjadi penunjang dalam peningkatan kinerja pengelolaan keuangan pemerintah. Kompensasi mempunyai fungsi yang cukup penting dalam bidang pemerintahan. Hal ini dikarenakan kompensasi berperan penting dalam menghubungkan organisasi dan para pegawainya. Selain itu, kompensasi juga sangat berpengaruh bagi kompetensi yang ada pada para pegawai dalam organisasi. Semakin baik pemberian kompensasi dalam organisasi maka akan memotivasi para pegawai untuk meningkatkan kompetensi yang dimiliki [8].

Kompensasi merupakan pendapatan yang dapat berbentuk uang, barang langsung maupun tidak langsung yang diterima oleh pegawai sebagai imbalan jasa yang diberikan oleh organisasi [9]. Selain itu kompensasi merupakan bentuk kembalian finansial, jasajasa berwujud dan tunjangan yang diperoleh pegawai sebagai bagian dari hubungan antara pegawai dan organisasi [10]. Dalam hal ini kompensasi finansial dibagi menjadi dua yaitu kompensasi tidak langsung dan kompensasi langsung, sedangkan kompensasi non finansial juga dikelompokkan berupa pekerjaan dan lingkungan pekerjaan. Melalui pemberian kompensasi, maka pegawai dapat termotivasi untuk meningkatkan keahlian, kinerjanya, dan lain-lain [8].

\section{METODE PENELITIAN}

Jenis data yang digunakan dalam penelitian ini adalah data kuantitatif. Data kuantitatif adalah data yang berbetuk angka atau data kualitatif yang diangkakan [11]. Data kuantitatif penelitian ini yang berupa nilai atau skor atas jawaban yang diberikan oleh responden terhadap pernyataan-pernyataan yang ada di dalam kuesioner.

Sumber data yang digunakan dalam penelitian ini adalah Data Primer. Data Primer adalah sumber data penelitian yang diperoleh secara langsung dari sumber asli . Data sekunder adalah data yang diperoleh secara tidak langsung melalui perantara [12]. Data primer penelitian ini adalah data yang diperoleh langsung dari Kantor Badan Pengelolaan Keuangan dan Asset Daerah (BPKAD) Kota Baubau, Sulawesi Tenggara. Sedangkan Data Sekunder penelitian ini, yaitu data hasil penelitian yang sudah pernah dilakukan sebelumnya, dimana data tersebut bersumber dari dokumen atau institusi lainnya, yang dianggap berkaitan atau relavan dengan pengaruh teknologi informasi, kompetensi dan 
kompensasi terhadap kinerja pengelolaan keuangan pada Kantor Badan Pengelolaan Keuangan dan Asset Daerah (BPKAD) Kota Baubau, Sulawesi Tenggara.

Populasi adalah keseluruhan objek penelitian yang memiliki karakteristik tertentu [13]. Populasi dalam penelitian ini adalah seluruh pegawai di Kantor Badan Pengelolaan Keuangan dan Asset Daerah (BPKAD) Kota Baubau, Sulawesi Tenggara sebanyak kurang lebih 53 orang. Sampel adalah sebagian atau wakil populasi yang diteliti [14]. Sampel dalam penelitian ini menggunakan metode sensus dikarenakan jumlah populasi dalam penelitian ini kurang dari 100 orang maka jumlah sampel yang diambil sama dengan jumlah populasi.

Metode pengumpulan data yang digunakan dalam penelitian ini adalah Studi Kepustakaan, yaitu penelitian dengan melakukan peninjauan pada berbagai pustaka dengan cara membaca atau mempelajari jurnal-jurnal yang relevan dengan penelitian ini, buku-buku literatur yang erat hubungannya dengan penelitian ini dan dapat menunjang pembahasan selanjutnya. Kuesioner, yaitu melakukan pengumpulan data melalui pembagian daftar pertanyaan kepada responden.

Metode analisis data yang digunakan dalam penelitian ini adalah regresi linear berganda, yaitu metode analisis untuk lebih dari satu variabel independen. Penelitian ini menggunakan program pengolahan data yaitu SPSS. Dalam penelitian ini, data dianalisis dengan menggunakan alat analisis yang terdiri dari:

a) Uji instrumen penelitian untuk menguji kualitas data menggunakan dua konsep yaitu Uji Validitas, digunakan untuk mengetahui sah atau tidaknya kuesioner penelitian. Uji dilakukan dengan membandingkan koefisien $r$ hitung dengan koefisien $r$ tabel. Apabila nilai $r$ hitung lebih besar dari $r$ tabel maka mengindikasikan item tersebut valid. Sebaliknya jika $r$ hitung lebih kecil dari $r$ tabel maka item penelitian tersebut tidak valid untuk digunakan. Uji reabilitas digunakan untuk mengukur kuesioner penelitian yang merupakan indikator dari konstruk atau variabel.

b) Uji asumsi klasik yang digunakan dalam penelitian ini terdiri atas Uji normalitas menguji apakah dalam model regresi, variabel pengganggu atau residual memiliki kontribusi normal atau tidak. Indikator model regresi yang baik adalah memiliki data terdistribusi normal atau mendekati normal yaitu dengan melihat analisis grafik atau uji statistik. Jika menggunakan grafik, normalitas dapat dideteksi dengan melihat tabel histogram. Apabila distribusi data adalah normal maka garis yang menggambarkan data sesungguhnya akan mengikuti garis diagonalnya. Untuk menguji normalitas 
residual pada uji statistik dapat digunakan uji statistik non-parametrik KolmogorovSmirnov (K-S), dengan membuat hipotesis:

1) $\mathrm{H} O$ : Data residual terdistribusi normal.

2) HA: Data residual tidak terdistribusi normal.

(i) Uji Multikoleniaritas berguna untuk menguji kemungkinan terdapat korelasi antar variabel independen yang satu dengan variabel independen yang lain. Dalam definisi sederhana, setiap variabel independen menjadi variabel dependen dan diregresi terhadap variabel bebas lainnya [15]. Jika antara variabel independen terdapat korelasi yang cukup tinggi $\left(\mathrm{R}^{2}>0,90\right)$ menandakan adanya multikoleniaritas.

(ii) Pengujian Hetereokedastisitas bertujuan untuk mengetahui apakah pada model regresi terjadi ketidaksamaan residual antara pengamatan satu dan pengamatan lainnya.

Pola tertentu yang timbul teratur menunjukkan terjadi hetereokedastisitas pada model regresi penelitian. Untuk memperkuat uji scatterplot terdapat cara lain yaitu dengan pengujian statistik uji park. Apabila variabel independen memiliki tingkat signifikasinya melebihi 0,05 maka disimpulkan tidak terjadi hetereokedastisitas dalam model regresi.

(i) Metode Analisis Data, ntuk mengolah data hasil penelitian maka peneliti menggunakan metode analisis sebagai berikut: (1) Metode Statistik deskriptif ini bertujuan untuk menguraikan secara deskriptif karakteristik responden dan variabel-variabel penelitian melalui distribusi frekuensi, rata-rata dan persentase. (2) Metode Regresi Berganda, uji regresi ini digunakan untuk menganalisis lebih dari satu variabel independen [15]. Persamaan regresi yang dirumuskan dalam penelitian ini adalah:

$$
Y=\alpha+b 1 X 1+b 2 X 2+b 3 X 3+e
$$

Keterangan:

$Y \quad=$ Kinerja pengelolaan keuangan

$\alpha=$ Konstanta (Intercept)

$b 1-b 3=$ Parameter

$\mathrm{X} 1=$ Teknologi informasi

$\mathrm{X} 2=$ kompetensi

$\mathrm{X} 3=$ kompensasi

$e \quad=$ Faktor kesalahan $($ Error random $)$ 
Pengujian hipotesis ini digunakan untuk mengukur kekuatan hubungan antara dua variabel atau lebih dan menunjukkan arah hubungan antara variabel dependen dan variabel bebas. Perhitungan hipotesis statistik disebut signifikan secara statistik apabila HO ditolak, sebaliknya disebut tidak signifikan apabila hasil uji statistiknya menunjukkan $\mathrm{H} O$ diterima [15]. Untuk mengukur fungsi regresi sampel apakah telah tepat secara statistik dapat diukur dari besarnya nilai koefisien determinan, nilai statistik $\mathrm{F}$ dan nilai statistik $\mathrm{t}$.

(ii) Uji Hipotesis, untuk menguji pengaruh variabel independen terhadap variabel dependen dilakukan dengan (1) uji statistik t menunjukkan tingkat pengaruh satu variabel independen secara individual dalam menerangkan variabel terikat. Uji t digunakan untuk menguji pengaruh variabel independen masing-masing. Dengan menggunakan $\mathrm{t}$ tabel pada uji $\mathrm{t}$, nilai t yang dihitung akan dibandingkan dengan nilai t pada tabel. Apabilai nilai t hitng lebih besar dari t tabel maka hipotesis awal diterima dan $\mathrm{HO}$ ditolak. Sebaliknya, apabila besarnya nilai t hitung lebih kecil dari nilai t tabel maka hipotesis awal ditolak dan $\mathrm{H} O$ diterima.

Adapun rumus uji statistik yang digunakan adalah:

$$
\begin{aligned}
& \mathrm{t}=\frac{r \sqrt{n-2}}{\sqrt{1}-r 2} \\
& \text { keterangan: } \\
& \mathrm{t} \quad=\mathrm{t} \text { hitung } \\
& \mathrm{r} \quad=\text { Koefisien korelasi } \\
& \mathrm{n} \quad=\text { Jumlah sampel }
\end{aligned}
$$

Bila hasil perhitungan menunjukkan $\mathrm{t}$ hitung $>\mathrm{t}$ tabel dengan tingkat kepercayaan $<0,05$ berarti variabel independen tersebut berpengaruh signifikan terhadap variabel dependen.

(2) Uji Serempak (Uji-F), uji statistik F digunakan untuk mengukur apakah semua variabel independen yang ada pada penelitian mempunyai pengaruh secara bersama, simultan terhadap variabel dependen [15]. Pada derajat 5\%, hipotesis alternatif diterima dan semua variabel independen secara signifikan mempengaruhi variabel dependen. 
Adapun rumus uji statistik yang digunakan adalah:

$$
\mathrm{F}=\frac{r 2(N m 1)}{m(-r 2)}
$$

keterangan:

$$
\begin{array}{ll}
\mathrm{F} & =\text { Harga F garis regresi } \\
\mathrm{N} & =\text { Jumlah Sampel } \\
\mathrm{m} & =\text { Jumlah Predictor } \\
\mathrm{R} & =\text { Koefisien korelasi antara kriterium dengan predikator }
\end{array}
$$

Bila hasil perhitungan menunjukkan nilai $\mathrm{F}$ hitung $>\mathrm{F}$ tabel dengan tingkat kepercayaan $<0,05$ berarti semua variabel independen secara simultan (bersamasama) berpengaruh terhadap variabel dependen.

(3) Uji Pengaruh Serempak (Determinasi, $R^{2}$ ), koefisien ini bertujuan untuk mengukur seberapa jauh model regresi dapat menerangkan variabel-variabel dependen penelitian. Nilai koefisien $\mathrm{R}^{2}$ antara nol dan satu. Nilai $\mathrm{R}^{2}$ yang kecil menandakan kemampuan variabel-variabel independen dalam menjelaskan variabel-variabel dependen terbatas [15]. Nilai mendekati satu, berarti hampir semua variabel dependen dapat diterangkan oleh variabel-variabel independen.

\section{HASIL DAN PEMBAHASAN}

\section{a. Hasil Penelitian}

Berdasarkan hasil penelitian terhadap seluruh pegawai Badan Pengelolaan Keuangan dan Asset Daerah (BPKAD) Kota Baubau meliputi 1 orang kepala BPKAD, 1 orang sekretaris, 4 orang kepala bidang, 3 orang kepala sub bagian, 8 orang kepala seksi, dan 36 orang staf.

\section{Hasil Uji Simultan (Uji F)}

Uji simultan digunakan untuk menguji ada tidaknya pengaruh dari variabel bebas secara menyeluruh terhadap variabel terikat dilakukan dengan menggunakan uji F. Uji ini menggunakan $\alpha$ 5\%. Dengan ketentuan, jika signifikansi < dari 0,05 maka hipotesis yang diajukan dapat diterima. Hasil pengujiannya sebagai berikut: 
Tabel 1 Hasil Uji Simultan (Uji F)

ANOVA

\begin{tabular}{|r|r|r|r|r|r|}
\hline \multicolumn{1}{|l|}{ Model } & $\begin{array}{r}\text { Sum of } \\
\text { Squares }\end{array}$ & Df & $\begin{array}{c}\text { Mean } \\
\text { Square }\end{array}$ & F & Sig. \\
\hline Regression & 123.118 & 3 & 41.039 & 5.456 & $.003^{\mathrm{b}}$ \\
1 Residual & 368.58 & 49 & 7.522 & & \\
\multicolumn{1}{|c|}{ Total } & 491.698 & 52 & & & \\
\hline
\end{tabular}

a. Dependent Variable: KinerjaPengelolaanKeuangan

b. Predictors: (Constant), Kompensasi, TeknologiInformasi,

\section{Kompetensi}

Sumber: Data primer yang diolah, 2016

Tabel 1 menunjukkan bahwa tingkat signifikansi lebih kecil dari 0,05, sehingga dapat dikatakan bahwa teknologi informasi, kompetensi dan kompensasi secara simultan (bersama-sama) mempunyai pengaruh terhadap kinerja pengelolaan keuangan, dengan probabilitas 0,003 . Karena probabilitas jauh lebih kecil dari nilai signifikan 0,05, maka model regresi dapat digunakan untuk memprediksi tingkat kinerja pengelolaan keuangan.

\section{Hasil Uji Parsial (Uji t)}

Uji parsial digunakan untuk melihat pengaruh masing-masing variabel independen terhadap variabel dependen. Pengujian dilakukan dengan uji t yaitu dengan melihat nilai signifikansi t hitung, Jika nilai signifikansi < dari 0,05 maka dapat dikatakan variabel independen tersebut mempunyai pengaruh terhadap variabel dependen. Hasil pengujiannya adalah sebagai berikut: 


\section{Tabel 2 Hasil Uji Parsial (Uji t) \\ Coefficients $^{\mathrm{a}}$}

\begin{tabular}{|c|c|c|c|c|c|}
\hline \multirow[t]{2}{*}{ Model } & \multicolumn{2}{|c|}{$\begin{array}{c}\text { Unstandardized } \\
\text { Coefficients }\end{array}$} & \multirow{2}{*}{\begin{tabular}{|c|} 
Standardized \\
Coefficients
\end{tabular}} & \multirow[t]{2}{*}{$\mathrm{T}$} & \multirow[t]{2}{*}{ Sig. } \\
\hline & $\bar{B}$ & Std. Error & & & \\
\hline (Constant) & 4.565 & 7.091 & & .644 & .523 \\
\hline Teknologi & .255 & .110 & .291 & 2.319 & .025 \\
\hline Informasi & & & & & \\
\hline Kompetensi & .252 & .112 & .281 & 2.244 & .029 \\
\hline Kompensasi & .288 & .125 & .285 & 2.294 & .026 \\
\hline
\end{tabular}

Sumber: Data primer yang diolah, 2016

Berdasarkan tabel 2 di atas, maka persamaan regresi yang terbentuk adalah:

$$
Y=4,565+0,255 X_{1}+0,252 X_{2}+0,288 X_{3}
$$

Model tersebut dapat diinterpretasikan sebagai berikut:

1) Nilai konstanta adalah 4,565 ini menunjukkan bahwa, jika variabel independen (teknologi informasi, kompetensi dan kompensasi) bernilai nol (0), maka nilai variabel dependen (kinerja pengelolaan keuangan) sebesar 4,565.

2) Koefisien regresi teknologi informasi $\left(b_{1}\right)$ adalah 0,255 dan bertanda positif. Hal ini berarti, nilai variabel Y mengalami kenaikan sebesar 0,255 yang disebabkan peningkatan nilai variabel $\mathrm{X}_{1}$, dan apabila variabel independen lainnya bernilai tetap. Koefisien bertanda positif menunjukkan adanya hubungan yang searah antara variabel teknologi informasi $\left(\mathrm{X}_{1}\right)$ dengan variabel kinerja pengelolaan keuangan $(\mathrm{Y})$. Semakin baik teknologi infomasi, maka kinerja pengelolaan keuangan akan semakin meningkat.

3) Koefisien regresi kompetensi $\left(b_{2}\right)$ adalah 0,252 dan bertanda positif. Hal ini berarti, nilai variabel $\mathrm{Y}$ mengalami kenaikan sebesar 0,252 yang disebabkan peningkatan nilai variabel $\mathrm{X}_{2}$, dan apabila variabel independen lainnya bernilai tetap. Koefisien bertanda positif menunjukkan adanya hubungan yang searah antara variabel 
kompetensi $\left(\mathrm{X}_{2}\right)$ dengan variabel kinerja pengelolaan keuangan $(\mathrm{Y})$. Semakin tinggi kompetensi yang dimiliki oleh pegawai maka kinerja pengelolaan keuangannya akan semakin meningkat.

4) Koefisien regresi kompensasi $\left(b_{3}\right)$ adalah 0,288 dan bertanda positif. Hal ini berarti, nilai variabel $\mathrm{Y}$ mengalami kenaikan sebesar 0,288 yang disebabkan peningkatan nilai variabel $\mathrm{X}_{3}$, dan apabila variabel independen lainnya bernilai tetap. Koefisien bertanda positif menunjukkan adanya hubungan yang searah antara kompensasi $\left(\mathrm{X}_{3}\right)$ dengan variabel kinerja pengelolaan keuangan (Y). Semakin tinggi kompensasi yang diterima oleh pegawai, maka akan membuat kinerja pengelolaan keuangannya semakin meningkat.

Melalui statistik uji-t yang terdiri dari Teknologi Informasi $\left(\mathrm{X}_{1}\right)$, Kompetensi $\left(\mathrm{X}_{2}\right)$, dan Kompensasi $\left(\mathrm{X}_{3}\right)$ dapat diketahui secara parsial pengaruhnya terhadap Kinerja Pengelolaan Keuangan (Y).

\section{a) Pengujian Hipotesis Pertama $\left(\mathrm{H}_{1}\right)$}

Tabel 2 menunjukkan bahwa variabel teknologi informasi memiliki tingkat signifikan sebesar 0,025 yaitu lebih kecil dari 0,05. Hal ini berarti $\mathbf{H}_{\mathbf{1}}$ diterima sehingga dapat dikatakan bahwa teknologi informasi berpengaruh signifikan terhadap kinerja pengelolaan keuangan. Nilai $t$ yang bernilai $+2,319$ menunjukkan pengaruh yang diberikan bersifat positif terhadap variabel dependen.

b) Pengujian Hipotesis Kedua $\left(\mathrm{H}_{2}\right)$

Tabel 2 menunjukkan bahwa variabel kompetensi memiliki tingkat signifikan sebesar 0,029 yaitu lebih kecil dari 0,05. Hal ini berarti $\mathbf{H}_{2}$ diterima sehingga dapat dikatakan bahwa kompetensi berpengaruh signifikan terhadap kinerja pengelolaan keuangan. Nilai $t$ yang bernilai $+2,244$ menunjukkan pengaruh yang diberikan bersifat positif terhadap variabel dependen

\section{c) Pengujian Hipotesis Ketiga $\left(\mathrm{H}_{3}\right)$}

Tabel 2 menunjukkan bahwa variabel kompensasi memiliki tingkat signifikan sebesar 0,026 yaitu lebih kecil dari 0,05. Hal ini berarti $\mathbf{H}_{\mathbf{3}}$ diterima sehingga dapat dikatakan bahwa kompensasi berpengaruh signifikan terhadap kinerja pengelolaan keuangan. Nilai $t$ yang bernilai $+2,294$ menunjukkan pengaruh yang diberikan bersifat positif terhadap variabel dependen. 


\section{3. $\mathbf{U j i} \mathbf{R}^{2}$ (Koefisien Determinasi)}

Uji koefisien determinasi bertujuan untuk mengetahui seberapa besar kemampuan variabel dependen dapat dijelaskan oleh variabel independen. Hasil uji koefisien determinasi $\left(\mathrm{R}^{2}\right)$ dapat dilihat pada tabel berikut:

\section{Tabel 3 Hasil Uji $\mathbf{R}^{2}$}

Model Summary ${ }^{\text {b }}$

\begin{tabular}{|l|r|r|r|r|}
\hline Model & \multicolumn{1}{|c|}{$\mathrm{R}$} & R Square & $\begin{array}{c}\text { Adjusted R } \\
\text { Square }\end{array}$ & $\begin{array}{c}\text { Std. Error of the } \\
\text { Estimate }\end{array}$ \\
\hline 1 & $.500^{\mathrm{a}}$ & .630 & .204 & 2.74263 \\
\hline
\end{tabular}

a. Predictors: (Constant), Kompensasi, TeknologiInformasi,

\section{Kompetensi}

b. Dependent Variable: KinerjaPengelolaanKeuangan

Sumber: Data primer yang diolah, 2016

Dari tabel 3 di atas terdapat angka R sebesar 0,500 yang menunjukkan bahwa hubungan antara kinerja pengelolaan keuangan dengan ketiga variabel independennya cukup kuat, karena berada di defenisi sangat kuat yang angkanya 0,5. Sedangkan nilai $\mathrm{R}$ square sebesar 0,630 atau $63 \%$ ini menunjukkan bahwa variabel kinerja pengelolaan keuangan dapat dijelaskan oleh variabel karakteristik teknologi informasi, kompetensi dan kompensasi sebesar $63 \%$ sedangkan sisanya $37 \%$ dapat dijelaskan dengan variabel lain yang tidak terdapat pada penelitian ini.

\section{b. Pembahasan}

Hasil penelitian menunjukkan variabel teknologi informasi, kompetensi dan kompensasi berpengaruh positif signifikan terhadap kinerja pengelolaan keuangan pada Badan Pengelolaan Keuangan dan Asset Daerah di Kota Baubau. Adapun pembahasan mengenai pengaruh teknologi informasi, kompetensi dan kompensasi terhadap kinerja pengelolaan keuangan pada BPKAD Kota Baubau, akan diuraikan sebagai berikut : 


\section{Pengaruh Teknologi Informasi Terhadap Kinerja Pengelolaan Keuangan}

Hasil pengujian menunjukkan bahwa variabel teknologi informasi berpengaruh positif dan signifikan terhadap kinerja pengelolaan keuangan. Hal ini berarti bahwa terdapat hubungan yang searah antara teknologi informasi dengan kinerja pengelolaan keuangan dalam arti apabila teknologi informasi yang digunakan dalam pengelolaan keuangan memiliki penguasaan secara baik maka kualitas dari pengelolaan keuangan juga akan baik.

Pengaruh signifikan teknologi informasi sangat ditentukan oleh besarnya peran indikator yang membentuk yakni (1) ketersediaan perangkat teknologi informasi, (2) sistem pelaporan akuntansi yang terkomputerisasi, (3) pemeliharaan perangkat, (4) perbaikan atau penggantian perangkat, (5) pelaksanaan tugas dengan menggunakan aplikasi akuntansi, (6) pengolahan data berdasarkan peraturan perundang-undangan, (7) ketersediaan sistem keamanan komputer, (8) ketersediaan jaringan internet sebagai penghubung antar unit kerja, (9) pelaporan yang dihasilkan berdasarkan sistem terintegrasi. Dari indikator-indikator yang membentuk variabel teknologi informasi tersebut, maka indikator pembentuk utama variabel teknologi informasi adalah indikator ketersediaan perangkat teknologi informasi, kemudian diikuti indikator sistem pelaporan akuntansi yang terkomputerisasi, dan pengolahan data berdasarkan peraturan perundang-undangan, serta pelaporan yang dihasilkan berdasarkan sistem yang terintegrasi. Sedangkan indikator-indikator yang lain memberikan proporsi kecil dalam membentuk variabel teknologi informasi, sehingga perlu ditingkatkan agar keandalan kinerja pengelolaan keuangan dapat dicapai sesuai dengan yang diharapkan.

Berdasarkan analisis tersebut maka dapat dinyatakan bahwa teknologi informasi merupakan faktor penting dalam peningkatan kinerja pengelolaan keuangan pada Badan Pengelolaan Keuangan dan Asset Daerah di Kota Baubau. Oleh karena itu, teknologi informasi perlu ditingkatkan terutama pada indikator pembentuknya agar kinerja pengelolaan keuangan dapat dimaksimalkan sesuai dengan yang diharapkan.

Hasil penelitian ini membuktikan bahwa teknologi informasi memberikan pengaruh positif dan signifikan terhadap kinerja pengelolaan keuangan pada Badan Pengelolaan Keuangan dan Asset Daerah di Kota Baubau, yang berarti semakin 
baik suatu sistem teknologi informasi maka kinerja pengelolaan keuangan juga akan semakin baik pula.

\section{Pengaruh Kompetensi Terhadap Kinerja Pengelolaan Keuangan}

Hasil pengujian menunjukkan bahwa variabel kompetensi berpengaruh positif dan signifikan terhadap kinerja pengelolaan keuangan. Hal ini berarti bahwa terdapat hubungan antara kompetensi dengan kinerja pengelolaan keuangan dalam arti apabila pengelola keuangan memiliki kompetensi yang baik maka kinerja yang dihasilkan dari pengelolaan keuangan tersebut juga akan baik.

Pengaruh signifikan kompetensi sangat ditentukan oleh besarnya peran indikator yang membentuk yakni (1) kemampuan pengoperasian komputer, (2) pengetahuan tentang teori keuangan dan bidang lainnya, (3) kemampuan berkomunikasi dengan baik, (4) kemampuan penyelesaian tugas, (5) kemampuan bekerja sama dengan tim, (6) memiliki semangat berkompetensi, (7) kepatuhan terhadap aturan, (8) penganggaran dana dengan semestinya, (9) pelaksanaan pelatihan untuk pengembangan dan penguasaan keahlian. Dari indikator-indikator yang membentuk variabel kompetensi tersebut, maka indikator pembentuk utama variabel kompetensi adalah indikator kemampuan penyelesaian tugas, lalu diikuti dengan indikator kemampuan kepatuhan aturan, dan indikator kemampuan berkomunikasi dengan baik. Sedangkan indikator-indikator yang lain memberikan proporsi kecil dalam membentuk variabel kompetensi, sehingga perlu ditingkatkan agar keandalan kinerja pengelolaan keuangan dapat dicapai sesuai dengan yang diharapkan.

Berdasarkan analisis tersebut maka dapat dinyatakan bahwa kompetensi merupakan faktor penting dalam meningkatkan kinerja pengelolaan keuangan pada Badan Pengelolaan Keuangan dan Asset Daerah di Kota Baubau.

\section{Pengaruh Kompensasi Terhadap Kinerja Pengelolaan Keuangan}

Hasil pengujian statistik menunjukkan bahwa kompensasi berpengaruh positif dan signifikan terhadap kinerja pengelolaan keuangan. Hal tersebut mengandung arti bahwa semakin tinggi kompensasi yang diterima, maka kinerja pengelolaan anggaran cenderung akan semakin meningkat.

Pengaruh signifikan kompensasi sangat ditentukan oleh besarnya peran indikator yang membentuk yakni kesesuaian gaji berdasarkan pangkat/golongan,sistem penggajian yang berdasarkan dengan aturan yang berlaku, 
adanya tunjangan sebagai motivasi kerja, adanya kesempatan bagi yang memiliki kinerja baik,adanya penghargaan terhadap penyelesaian tugas dengan baik, kesejahteraan pegawai. Dari indikator-indikator yang membentuk variabel kompensasi tersebut, maka indikator pembentuk utama variabel kompensasi adalah indikator sistem penggajian yang berdasarkan dengan aturan yang berlaku, kemudian diikuti indikator kesesuaian gaji berdasarkan pangkat/golongan, dan indikator adanya tunjangan sebagai motivasi kerja. Sedangkan indikator-indikator yang lain memberikan proporsi kecil dalam membentuk variabel kompensasi, sehingga perlu ditingkatkan agar keandalan kinerja pengelolaan keuangan dapat dicapai sesuai dengan yang diharapkan.

Berdasarkan hasil tersebut, dapat dipahami bahwa kompensasi yang tinggi dapat mempengaruhi kinerja pengelolaan keuangan pada Badan Pengelolaan Keuangan dan Asset Daerah Kota Baubau.

\section{KESIMPULAN}

Penelitian ini bertujuan untuk mengetahui pengaruh teknologi informasi, kompetensi, dan kompensasi terhadap kinerja pengelolaan keuangan pada badan pengelolaan keuangan dan asset daerah (BPKAD) Kota Baubau. Berdasarkan hasil penelitian maka dapat diambil kesimpulan sebagai berikut (1) Teknologi informasi berpengaruh positif dan signifikan terhadap kinerja pengelolaan keuangan pada Badan Pengelolaan Keuangan dan Asset Daerah di Kota Baubau. Semakin baik penggunaan dan sistem teknologi informasi yang digunakan maka kinerja pengelolaan keuangan akan semakin baik pula. (2) Kompetensi berpengaruh positif dan signifikan terhadap kinerja pengelolaan keuangan pada Badan Pengelolaan Keuangan dan Asset Daerah di Kota Baubau. Apabila pengelola keuangan memiliki kompetensi yang baik maka kinerja yang dihasilkan dari pengelolaan keuangan tersebut juga akan baik. (3) Kompensasi berpengaruh positif dan signifikan terhadap kinerja pengelolaan keuangan pada Badan Pengelolaan Keuangan dan Asset Daerah di Kota Baubau. Pemberian kompensasi yang cukup baik pada karyawan yang berprestasi baik, akan mendorong para karyawan untuk bekerja dengan lebih baik dan ke arah pekerjaan-pekerjaan yang lebih produktif. Dengan kata lain, Pemberian kompensasi yang cukup baik pada karyawan yang berprestasi dapat meningkatkan kinerja pengelolaan keuangan suatu organisasi. 


\section{SARAN}

Berdasarkan hasil penelitian yang dilakukan mengenai pengaruh teknologi informasi, kompetensi dan kompensasi terhadap kinerja pengelolaan keuangan pada badan pengelolaan keuangan dan asset daerah (BPKAD) di Kota Baubau, maka hal-hal yang dapat disarankan sebagai berikut (1) Bagi peneliti selanjutnya disarankan untuk menguji variabel-variabel lainnya yang berpengaruh terhadap kinerja pengelolaan keuangan seperti motivasi kerja, partisipasi anggaran, pembelajaran organisasi, dan variabel-variabel pendukung lainnya. (2) Bagi peneliti selanjutnya disarankan agar menambah indikator-indikator lainnya guna memperoleh hasil penelitian yang lebih akurat.

\section{DAFTAR PUSTAKA}

[1] Ardi, Bagus Kusuma. 2013. Pengaruh Kemajuan Teknologi Informasi Terhadap Perkembangan Sistem Informasi Akuntansi. STIE Dharmaputra: Semarang. (http://ejurnal.stiedharmaputra-smg.ac.id/index.php/DE/article/download/30/30).

[2] Sabyasachi, Mitra and Chaya Antonie Karim. 1996. Analyzing Cost Effectiveness of Organizations: The Impact of Organization Technology Spending. Journal of Management Information System.

[3] Satriyo, M. Zuchri. 2011. Pengaruh Kompetensi, Partisipasi Anggaran dan Pembelajaran Organisasi Terhadap Kinerja Pengelolaan Keuangan Daerah (Studi kasus pada dinas pendapatan, pengelolaan keuangan, dan aset Kabupaten Bangka Barat). Program Pascasarjana Universitas Terbuka Jakarta.

[4] Bilbeg, Ashis. 22 Maret 2013. Analisis Rasio untuk Mengukur Kinerja Pengelolaan Keuangan Provinsi Sulawesi Selatan.).

[5] Fitriyani, Riska. 2014. Pengaruh Penggunaan Teknologi Informasi, Keahlian Pemakai dan Intensitas Pemakaian Terhadap Kualitas Informasi Akuntansi. Universitas Bengkulu.

[6] Enceng,Liestyodono dan Purwaningdyah. 2008. Meningkatkan Kompetensi Aparatur Pemerintah Daerah dalam Mewujudkan Good Governance. Jurnal Kebijakan dan Manajemen. Vol. 2: 12-15

[7] Simanjuntak, Hakim. 2013. Pengertian dan Tujuan Pengukuran Kinerja Keuangan. (http://cybon.blogspot.co.id/2013/02/pengertian-dan-tujuan-pengukuran.html).

[8] Wiguna, Candra. 2015. 18 November 2015. Dunia Iptek: Kompensasi dalam Manajemen Sumber Daya Manusia. (http://duniaiptek.com/kompensasi-dalammanajemen-sumber-daya-manusia/). 
[9] Dessler, Gary. 2015. Manajemen Sumber Daya Manusia, Edisi 14. Jakarta : salemba Empat.

[10] Henry Simamora, 2012. Manajemen Sumber Daya Manusia. Edisi 1. Yogyakarta: STIE YKPN Yogyakarta.

[11] Sugiyono, 2013. Metode Penelitian Bisnis. Bandung : Alfabeta.

[12] Ghozali, Imam. 2011. Aplikasi Analisis Multivariate dengan Program SPSS, Edisi Kelima. Badan Penerbit Universitas Diponegoro: Semarang.

[13] Usman Rianse, dan Abdi. 2008. Metodologi Penelitian Sosial dan Ekonomi. Teori Aplikasi. Bandung : Alfabeta.

[14] Arikunto, Suharsimi. 2013. Prosedur Penelitian Suatu Pendekatan Praktek. Jakarta: Rineka Cipta

[15] Ghozali, Imam. 2011. Aplikasi Analisis Multivariate dengan Program SPSS, Edisi Kelima. Badan Penerbit Universitas Diponegoro: Semarang. 